\title{
Vengeance with a Vengeance: Is it Worth to Study it?
}

\section{Autopsia de la Venganza: ¿Merece la Pena su Estudio?}

\author{
Nereida Bueno Guerra \\ Universidad Camilo José Cela, España
}

\begin{abstract}
Frijda (1994) warned that there was no major psychological study on vengeance, encouraging researchers to explore it. In the present article, an updated bibliographic search is done yielding similar conclusions but this time stating four arguments (cultural, judicial, criminal and psychological and social) to justify its study, concluding how society and individuals would benefit from it. Desires of vengeance (DoV) usually underlies the most prevalent crime in Spain. Some victims of bullying and mobbing can harbor DoV and turn into aggressors. In order to achieve a more objective judicial system, the measure of vindictive bias in juries may be helpful, as well as doing it within inmates, to assess risk of recidivism. From ancient to current times, DoV have modulated penal code modifications. These and some other reasons and possible future lines of research are shown to eventually propose an interdisciplinary study and further research so that from common effort of different disciplines we can achieve new knowledge of the matter.
\end{abstract}

Keywords: vengeance, revenge, retaliation, reciprocity, interdisciplinary, research.

Resumen. Frijda (1994) advirtió de que no existía ningún estudio profundo sobre la venganza, animando a los investigadores a explorar este campo. En el presente artículo se ha llevado a cabo una búsqueda bibliográfica actualizada obteniendo resultados similares, pero esta vez planteando cuatro argumentos (culturales, judiciales, psicológicos, criminológicos y sociales) para justificar su estudio, concluyendo cómo la sociedad y los individuos pueden beneficiarse si se investiga sobre los deseos de venganza (DdV). Los DdV normalmente subyacen al crimen con más prevalencia de España. Algunas víctimas de bullying y mobbing pueden albergar DdV y convertirse en agresores. Para lograr un sistema judicial más objetivo, medir los sesgos vengativos en jurados populares sería útil, así como hacerlo con internos penitenciarios para evaluar el riesgo de reincidencia. Desde tiempos remotos hasta el presente, los DdV han modulado modificaciones de códigos penales. Estas y otras razones así como posibles futuras líneas de investigación son esgrimidas en el texto para finalmente proponer más investigación desde la óptica interdisciplinar, de manera que del esfuerzo común de distintas disciplinas se logre nuevo conocimiento sobre la materia.

Palabras clave: venganza, revancha, reciprocidad, interdisciplinariedad, investigación.

\author{
HAMLET: “¡Oh! ¡Vengueance!” \\ (Act II, scene II. Hamlet, Shakespeare) \\ Andrò d'Acheronte \\ sù le nera sponda,
}

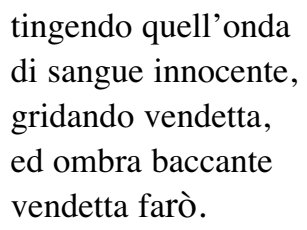
vendetta farò.

(Cantata RV 684. Cessate, omai cessate. Vivaldi) 


\section{Introduction}

Let me start the present article in a non-orthodox way. In 1940 the comic book artist Bob Kane gave birth to the first number of Batman's series. Its frames told the story of a young boy named Bruce Wayne, that went to the cinema with his parents and at the end of the show, on the street, witnessed them being murdered by a common criminal. Next scenes portrayed this recent orphan claiming: "Dead... They are dead! I swear by the spirits of my parents to avenge their deaths by spending the rest of my life warring on all criminals" (Kane, 1940).

This fiction reading led me to a reflection: could a subject change his whole life, his identity, even his vital objectives, just in pursuit of a desire of vengeance (DoV)? Would that thirst of vengeance stop if he could get even with the person that caused his damage? That is, would the superhero disappear once he could kill his parent's murderer?

Inspired by the "Gunpowder Plot", a real event held in London 1605, where some Catholics planned burning down the House of Lords, a new comic is released, "V for Vendetta". Alan Moore and David Lloyd created a character that, battered by a totalitarian government, devises his revenge. For that purpose, he is endowed with a sinister patience: "For 20 years, I sought only this day". (Moore, 1988).

For how long could a DoV be active? Is it an emotion (traditionally considered "hot"), a cognition ("cold" if we borrow the famous quote from "Les liaisons dangereuses") or is it an interrelation among both? Going further: from an evolutionary perspective, what does the avenger get with his revenge if it implies big efforts and he cannot restore the damage caused? Batman cannot bring his parents to life again and $\mathrm{V}$ cannot recover his past suffering.

Trying to answer these questions I found that Frijda (1994) had already emphasized, during the congress about emotions that was held in his honor in the Netherlands, the need of better exploring the DoV: "No major psychological study has appeared on the topic during the last 70 or 80 years. A literature search from 1967 to 1991 yielded not a single study having "vengeance" or "revenge" as its main subject. (...) It should be a task of the psychology of emotion to devote attention to the properties of wrath, that is, of such anger as leads to vengeful fantasies and actions. (...) What is important is to understand particular functional features, and see how they relate to other functional features. It is such features that should hold center stage” (p.264265).

In fact, during next decade, Vidmar (2000) endorse Frijda's review concluding that there is little empiric information available about prevalence of DoV, which does not help to clinicians in their therapeutic interventions, given that $\mathrm{DoV}$ is not adequately addressed in the literature for general psychiatrists (Horowitz, 2007).

In the purpose of bringing up to date the literature search, I did a new and updated bibliographic search (publications later to 2000 until March 2011) in four major data basis, also taking "vengeance" and "revenge" as key words, refining the search to studies considering its properties or functional features as its main subject, and also refining to "clinical psychology", "experimental psychology" and "social psychology" (so that judicial or literary analysis were excluded), yielding similar results to those announced by Frijda in the nineties (Pubmed: 16; PsycInfo: 2; Web of Knowledge: 22).

Even if we look up the contents of one of the main handbooks of emotions, as Lewis, Havilland-Jones \& Barrett's (2008), words related to vengeance (revenge, vengeance, wrath, retaliate, vengefulness), we only have two results considering vengeance briefly. So the question is: do we need to care about the DoV? Is it present enough in our lives so that we would need to pay attention to it? What are the consequences of the DoV?

Thus, in the present article, given that there is little deeply study about vengeance or revenge, it is going to be used the term "desire of vengeance" (DoV) as the core concept, meaning a cognitive assumption elaborated and maintained by a subject that perceived having been intentionally damaged before (both intention and damage were real or not). "Vengeance" itself will be considered as the act chosen by a subject to put into action his/her DoV, that is, a further decisional step with factual consequences outside. In this sense, the main interest of this study will be exploring the reasons that justify the need of studying the DoV, as the prelude of a possi- 
ble future vengeance, and it will be done from four different perspectives (cultural, judicial, criminalpsychological and social), so that it could appear as a fruitful but forgotten field of research, with many clinical and social repercussions, and very useful to investigate for living peacefully in society.

\section{Cultural reasons}

Men talk and write about what they care. In fact, it is not strange trusting in the study of language and literature to find psychological clues that contribute to the establishment of theoretical models. As an example, during the sixties, Big Five model of personality from Costa \& McCrae (1992) adopted a lexical approach assuming the idea that most relevant individual differences remain encoded as a last resort in the form of adjectives and expressions, so that the human linguistic knowledge was the reflection of the knowledge about human personality factors. Thus, the more important a factor was, the more languages would have a term for it (SánchezBernardos, 1997). Therefore, it could be said that what was relevant for human beings have been inserted in their folklore and texts, in their vocabulary and history. Psychology should not obviate this source of valuable information which is linguistics and literature, so that applying its methodology, it could obtain new knowledge.

In this sense, it is interesting having a look to the German word referring to the pleasure produced by other's misfortune: "Schadenfreude", composed by "Schaden" (damage) and "Freude" (joy), and these in turn coming from Greek's "epichairekakia". This Greek term was described by Aristotle in his "Nicomachean Ethics" as a part of a trio, accompanying envy (phthonos) and vengeance (nemesis). So the subtle difference between them would be that whereas vengeance implies harm response to nondeserved other's fortune, and envy consists of harm response to every other's fortune, deserved or not, epichairekakia would define people enjoying other's misfortune. Thus, it seems that deserve and pleasure are the two aspects involved in the definitions. On the other hand, English-speaking countries also keep an expression with a similar meaning, "Roman holi- day", coming from the metaphor used by Lord Byron describing a gladiator who is waiting for being "butcher'd to make a Roman holiday", as a synonym of the keenness of pleasure felt by the audience witnessing his suffering and the celebration that would be held after the show. Thus, the sadistic component may differentiate this term from vengeance, being closer to Latinism "delectation morosa", meaning the habit of enjoying harmful thoughts about others. Therefore, regarding linguistics, both sadism and vengeance would lay in the field of pleasure, however, DoV would always have a justified reason for the avenger, coming from a prior damage, and sadism would be a more arbitrary feeling. Now, outlining the concept, would there it be traces of this along literature worldwide?

A quick look to our past led us to mythology as a collection of tales that belongs to a culture and that can be secularized to report fruitful information about the way of thinking and the technology availability of ancient civilizations, so that the myth turns into a valuable mean of research with the scientific help of some disciplines, such as philology or psychology (Grimal, 1979). Some other authors support this interdisciplinarity talking about the cooperation of philosophy, psychology, sociology, anthropology, poets, producers and novelists (Solomon, 1994). It is not said "reading and believing", but looking up and exploring which now well-known psychological aspects were used with ancient heroes and what characteristics were attributed to them.

From envy in the Judgment of Paris to vanity in Narciso's myth, Ancient Greek is a good example of how human beings, devoid of our present technology and of alternative didactic resources, needed to create stories anthropomorphizing reality, where images utterly embodied the feelings of Greeks (Grimal, 1989). And they wrote about vengeance. That is why, observing and analyzing myths, we could approach to the idea that ancient Greek had about the DoV.

Vengeance had a deity: Nemesis, the goddess of balance. According to some authors, she was depicted as the personification of the moral feeling that compared the happiness and the misfortune of mortals punishing those who caused an imbalance. So if this was vengeance for Greeks, we could understand 
that talking about balance and punishment, it seemed to inform about emotional basis lines that could be altered by events, producing an imbalance. That imbalance could have an urge to be necessarily restored by homeostasis, so that vengeance would be a natural, compulsory and even comprehensible reaction in the form of a punishment that Greeks could ascribe to perceived losses, although they knew that the punishment could not recover their lost object.

Erinyes ("those who can't be named") or also called Furies, were a trio of deities in charge of punishing the unpunished criminals. They were Tisiphone, vengeful destruction; Alecto, remorse, and Megaera, hate. As a result of Orestes myth from Aeschylus, that narrates how Orestes kills his mother because she had previously killed his father, who in turn had previously killed his sister, this trio became called Eumenides ("benevolents"). This domestic succession of crimes would have reached its climax when Orestes went to Delphic Oracle looking for the compassion of Apolo, and Erinyes, who had heard his matricide, decided punishing him by chasing and tormenting him with remorse. However, a judgment is held, in which vengeance is substituted by a system of arguments assessment where Erinyes agree about suspending their punishment, being called Eumenides so far and emerging a worship to this figures that firstly represented a retributive system, although some other versions tell other finals.

In this sense, it could be seen that it may be a need of getting even with the subject who causes the damage: no crime can lay unpunished. In fact, Greeks established a specific mechanism to avoid it: Eyrines, the personification of the DoV, the reaction to a suffering. But there is a lack of nuance in the myth: the proportionality. Damage is returned in the form of a punishment, but it is not specified the measure, so the factors that take part in the perception of loss and imbalance, and the factors that measure the extent of both damage and punishment, are out of scene. And so, this absence does not allow establishing limits to the DoV. Anyway, the DoV, firstly seemed as socially reprobated, adopted a judicial shape as a natural right. Humanity was asking for justice, and centuries ago, DoV had some part in it.

But myths are not the only literature that has tal- ked about DoV. From Medea by Euripides to Hamlet or Otelo by Shakespeare; from "The punishment without vengeance" by Lope de Vega to Dumas' count of Monte Cristo; from Moby Dick to Lee Geum-Ja in one of the films that compose the trilogy by Park Chan Wook; from Kill Bill to the manga Lone Wolf and cub, DoV and vengeance have been present as a useless way of recovering a valuable loss but as a satisfactory and sometimes also regretful way of response to it. Infidelity, murderer, fake testimony... have been some of the matters that arises DoV and that without a proportionality fixed, can perpetuate criminality. Thus, its existence and its relevance and subtle differences with other human passions have not gone unnoticed by several languages and by relevant authors in such different times, from German to Latin, from Ancient Greek to our days, and despite that, there is no major psychological or empirical research about this desire. Maybe humanity is shouting, and researchers are not listening to.

\section{Judicial reasons}

"An eye for an eye" is perhaps the most popular quote from Lex Talionis. A statement that may sound archaic in our culture because it does not seem appropriate to our concept of present humanrights defense Justice, but that supposed in that time a step further to the formal execution of revenge and extensively, to the formal execution of Justice. It was mentioned before that mythology might have forgotten specifying proportionality in vindictive punishments, so that prior seek and need for revenge had no limits. If someone stole my harvest, I could steal his harvest, kill his son or rape his wife. There was no proportionality, so, on the one hand, an endless cycle of revenge-revenge in return (my father was killed, I kill the offender, his son will kill me and so on) was produced and, on the other hand, if the victim had no means or wasn't strong enough, may not be able to get even with the offender, laying undefended. Thus, best solution to avoid violence perpetuation and defenseless victims, was bestowing the right of taking revenge to a third objective and independent power which would receive the 
approval of a concrete society both to establishing the reprobated conducts and to specifying their concrete and proportionated punishments. Lex Talionis (Latin adjective talis-tale means "equal") indicated that losing an eye must be payback with the same action to the offender, that is, also losing an eye and no more than that, deterring this way insatiable and immeasurable DoV that emerges from estimations of those wounded (as a real example we can find the quote attributed to Paquita González: "I must hurt you more than you've hurt me", a Spanish woman nicknamed "Santomera witch" by mass-media that presumably killed her children to get even with her husband for not paying enough attention to her).

This beginning of a retributive system can be found along cultures in Hammurabi Code, Manu Code of India, Hebraic Law or Roman Twelve Tables. However, proportionality can have some anthropological differences appearing to be far away from fairness: blood vengeance in Arabic-beduinen cultures (Al-Krenawi \& Graham, 1999); commiting suicide in Papua Nueva Guinea after being mistreated so that victim's family drives to get even with the offender (Counts, 1987); in some regions of India amputating the nose of thieves and war prisoners (Mazzola, 2007) or noses from women considered unfaithful or unworthy in many Middle East of Asia regions such as Afghanistan, as a symbol of public humiliation (as an example, see Aisha case, portrayed in Times cover $9^{\text {th }}$ August 2010), what is called honor crimes and that is also shaped as spewing acid to her faces; or even death penalty, a vindictive procedure still active in 67 countries in 2010 (Amnesty International, 2011).

Trying to balance legal responses to criminal acts, next step was introducing a monetary value as a mean of compensation, so that victim could receive a response to his/her damage without causing a new crime by punishing the offender. This change, called restorative justice, is one of the most extended procedures nowadays (as an example, Law $32 / 1999,8^{\text {th }}$ October, on Solidarity with victims of terrorism in Spain, in which State may provide a stipulated monetary amount to victims of terrorism).

And what about Asia? Nippon society had a complex system of social stratification that assigned different rights to different hierarchies. For instance, an extended punishment among Samurais, "seppuku", consisted of allowing the offender to commit suicide instead of being executed, so that it was understood that he could keep his dignity even during the final act of death. This seppuku would entail a strict and ruled ceremonial disembowelment wearing special clothes, writing a death poem, using specific arms and selecting a trustworthy assistant, everything held in front of spectators and keeping a profound sense of respect. However, other castes would die by different methods, pointing the idea that justice and punishment were based on social structure.

Moreover, it also existed a complex system of values, where honor, loyalty and inherited family values took a central position. The Ethics of Confucius claimed at its fourth chapter: "With him who has slain his father, a son should not live under the same sky" (Menander, 2005), implicitly claiming the allowance to get even in blood crimes. Perhaps inspired in this morality, in pre-modern Japan, katakiuchi was an accepted way to punish the perpetrators of murder against certain blood relations among the samurai class (Mills, 1976) specifying its limits: No second revenge was recognized in any form whatever: thus, if A murdered B and B's son killed A in revenge, A's son had no claim legally or morally to avenge his father's death. In fact, we can find lots of stories and woodblock prints describing this practices, such as "The history of Soga brothers" (Chikanobu, 1891) or loyalty revenge, as the real "47 Ronin", in which a cohort of 47 Samurai serfs carefully planned during a year the vengeance for their master's death: quitted their jobs, became monks or got married to the offender's palace architect's daughter, so they went unnoticed, got the palace's plan and beheaded their master's assassin with the same sword their master had died. Given their caste and their underlying motivation, they were condemned to seppuku. As it can be seen, cultural values, concept of Justice and social division can modulate the concept of vengeance as well.

Just only 140 years ago, that law changed. Five years after the Meiji Restoration, on the seventh of the second month of 1873 , the Japanese Government issued the following decree (Mills, 1976):

The taking of human life is strictly prohibited by the law of the land, and the right to punish a mur- 
derer lies with the Government. However, since ancient times it has been customarily regarded as the duty of a son or younger brother to avenge the murder of his father or elder brother. While this is a natural expression of the deepest human feelings, it is ultimately a serious breach of the law on account of private enmity, an usurpation for private purposes of public authority, and cannot be treated as other than the crime of wilful slaughter. Furthermore, in extreme cases the undesirable situation often arises that one person wantonly and deliberately kills another in the name of revenge without regard for the rights and wrongs of the case or the justification for his act. This is to be deplored, and it is therefore decreed that vengeance shall be strictly prohibited. In future, should some close relative unfortunately be killed, the facts should be set out clearly an a complaint be laid before the authorities. Let it be plainly understood that anyone who ignores this injunction and adheres to the old customs, taking the law into his own hands to kill for revenge, will be subject to a penalty appropriate to his offence.

Eventually, in Japan, eye for an eye Justice is substituted by a blind Justice, in which the DoV is snatched from free use of people and also bestowed to a third objective and independent power, being criminally reprobated to getting even, despite the old customs. However, the legislator realized that $\mathrm{DoV}$ is deeply rooted in social operation ("since ancient times...customarily"); he also knows that he is questioning an anthropological value ("natural expression...duty") going against justified centuries of clan disputes and blood shed. Precisely because of that he insists so much in the new prohibition ("deplored...strictly prohibited... anyone who adheres to the old customs...offence"), announcing the birth of a new social system in which guilty must be judicially proved to a third party.

Furthermore, this urge to remove DoV from Justice had leaded some legislation not only to think about victims and offenders, but also to think about juries. Many democratic nations tend to promote citizens participation in judiciary power as members of juries, but in order to protect objective resolutions, social psychology had the challenge to settle channels that allow the configuration of groups without social prejudices or emotional and vindictive bias that could influence their decisions upon defendants. In this sense, some studies have been conducted to explore DoV in candidates to be jury (Ho, FosterLee, FosterLee \& Crofts, 2002; Stuckless \& Goranson, 1992), finding that some admit they seek vengeance upon murderers so that those who kill would deserve to die and suffer the pain and terror of their victims (Brownlee, McGraw, \& Vest 1997; Nygaard, 1994). And eye for an eye turns incompatible with blind Justice.

Thus, having had a look to some penal legislations, it seems that the DoV has evolved from an individual right to an independent third party assessment, from an arbitrary and free use to a proportionated measure, from a retributive to a more restorative system. From West to East, both ancient codes and current laws have considered the DoV as a core matter in their inspiring principles of the operation of human society: by modifying values and customs (McKee \& Feather, 2008), by protecting rights and trying to deter infinite violent cycles or biased decisions in juries, the improvement of the concept of Justice has been pursued but, despite all of that effort, centuries and people worldwide involved, there is no major psychological or empirical research that had studied the DoV enough.

\section{Criminal and psychological reasons}

Could any psychological disorder be prone to harbor DoV or to act vindictively? Which is the prevalence of crimes pursuing a vindictive goal? As far as it is known, the DoV is implied in a wide rank of antisocial and criminal acts (Holbrook, 1997), finding this motivation underlying some crimes: employee's theft (Terris \& Jones, 1982); rape (Scully \& Marolla, 1985); sexual aggression (Ney, 1987); homicide (Porporino, Doherty \& Sawatsky, 1987); shop-lifting (Turner \& Cashdan, 1988); vandalism (Wiesenthal, 1990); pyromania (Noreik \& Grünfeld, 1990), traffic delinquency (Wiesenthal, Henessy \& Gibson, 2000) or even mafia, if we attend to general knowledge about its operation. It is seen that from minor offences to terrible crimes, DoV can be a trigger for its commission, data of par- 
ticular interest if we check the prevalence of some of these crimes in Spain during 2010: within a total of 213.878 crimes condemned, $79.111(36,9 \%)$ were road safety offences; 637 (0.29\%) were homicides; $341(0.15 \%)$ were sexual aggressions and 156 $(0.07 \%)$ were arson attacks (INE, 2012). That is, we know the prevalence and we know one of its possible motivations, but there is a lack of statistical information on how many of those crimes was commited in pursuit of a DoV. However, if results from international data could be extrapolated to Spain, it is yielded that one of the motivations underlying the most prevalent crime in our country could have been the DoV. This result may encourage future research on the study of how DoV arises and how is related to criminal offenses, so that prevention policies could be settled to protect our society and reduce criminal rates.

Prison is one of the possible penalties sentenced to a condemned person, and research has shown that $\mathrm{DoV}$ is also commonly present among inmates (Ohlsson \& Ireland 2011; Stuckless, Ford \& Vitelli, 1995) and even among young offenders (Pardini, 2011). The perception of being object of a betrayal or taking away their freedom by itself, could be at the root causes of this desire. Anyway, if we know as we could see above that DoV is one of the factors related to crime offenses; DoV could be considered as a criminal recidivism factor to take into account when risk assessment for releasing is done by prison psychologists. However, none of the five most internationally widespread instruments of risk assessment: HCR-20 (Douglas, Webster, Hart, Eaves \& Ogloff, 2001), SORAG, VRAG (Quinsey, Harris, Rice \& Cormier, 2006), RRASOR (Hanson, 1997) or SARA (Kropp, Hart, Webster \& Eaves, 1995) have included measures of the DoV as one of the mandatory factors to assess. Could it be proposed to explore DoV as a possible factor to be assessed given that some crimes are committed in pursuit of a DoV and we intuitively know that some inmates feel it?

Regarding offenders, studies have shown that some people diagnosed with specific psychological disorders, if acting violently, it might be because of a DoV. Avoidance personality disorder, for example, usually implies insecurity, disappointment or resent- ment that could be the origin of violent actions such as sexual abuse and aggression (Leue, Borchard \& Hoyer, 2004; Marshall, 2007), drugs and suicide (Dunsieth Nelson, Brusman-Lovins, Holcomb, Beckman, Welge, Roby, Taylor, Soutullo, \& Mcelroy, 2004; González, 2007). They would like to enjoy human contact but they could not manage it, so some could blame others because of this incapability, harboring DoV to them because they feel rejected (Esbec \& Echeburúa, 2010) and perhaps deciding committing a crime. On the other hand, paranoids are suspicious, usually tend to misinterpret minimal gestures or objective facts attributing malicious intentions to others, and rarely forget an insult (Novaco, 2010). Humiliation, embarrassment or jealousy are frequently found in paranoids, being DoV the fundamental motivation (Carroll, 2009; Esbec \& Echeburúa, 2010). Moreover, the association between paranoid disorder and schizoid disorder becomes especially dangerous, as these individuals may feel bitter about how they think society has treated them, harboring negative emotions such as rage and vengeance (Esbec \& Echeburúa, 2010) and occasionally acting violently: a research conducted by Stone (2001) yielded that $47 \%$ out of 99 serial killers analyzed fulfilled schizoid criteria. Furthermore, some mass murderer, partner aggressors or individuals retired from jobs serving society such as military, have shown high levels of paranoia likely to harbor both DoV and traumatic symptoms (Dutton, 2007).

In fact, feelings of revenge have often been found correlating with symptoms of posttraumatic stress disorder (PTSD) (Kunst, 2011), although they probably vary across populations and subgroups (Horowitz, 2007). Studies conducted with victims of war (Albania and Kosovo: Cardozo, Kaiser, Gotway \& Agani, 2003; Cambodia: Sonis, Gibson, de Jong, Field, Hean \& Komproe, 2009; Palestine and Israel: Hamama-Raz, Solomon, Cohen \& Laufer, 2008; Great Lakes Region, Uganda and El Congo: Bayer, Klasen \& Adam, 2007), yield that DoV could be harbored both among children and adults during months or even years after the incident, especially if the incident provoked psychopathological symptoms such as PTSD. Thus, children who showed more PTSD symptoms had significantly less 
openness to reconciliation $($ rho $=-0.34, \mathrm{P}<.001)$ and more feelings of revenge ( rho $=0.29, \mathrm{P}<.001$ ) in a study conducted with 169 child soldiers from Uganda and Congo (Bayer, et al. 2007). On the other hand, Cardozo and his colleagues (2003), assuming a $95 \%$ confidence interval, found in 1.999 that $62,1 \%$ out of 1.368 Kosovar victims of war with PTSD harbored DoV. Just a year after, it was still a $59 \%$ out of 1.399 ( $\mathrm{P}<.05$ in both). A warning is made in this sense, not only for the probability of criminality but also because cognitions and feelings of revenge may act as maintaining factors of PTSD throughout subjects life (Gäbler \& Maercker, 2011), involving subject's quality of life. However, others authors (Sonis et al, 2009), pointed out the opposite relation, finding that individuals harboring DoV were more likely to further develop PTSD than those without DoV, although not significantly. In both cases, given that DoV could persist over years or even decades (Frijda, 1994; Gäbler \& Maercker, 2011), time is a relevant factor as it was shown a positive association among PTSD symptoms and feelings of revenge during adult life. Regarding this, it must be said that feelings of revenge mean an adaptative appraisal response at first victimization stages, becoming a problem if they are kept for a long time (Orth, Montada \& Maercker, 2006).

But not only victims of war develop PTSD. Clinicians may regularly face this diagnose finding intrusive and persistent DoV associated with feelings of rage at perpetrators (Horowitz, 2001; Orth et al., 2006), and even though revenge fantasies have been discussed in the literature on PTSD (Milgram, Stern \& Levin, 2006) and also on complicated grief or other stress response syndromes, and these fantasies may even include rage at the self and lead to suicide, they are not adequately addressed in the literature for general psychiatrists, however (Horowitz, 2007).

Thus, although it has been shown that the most prevalent crime in Spain, and many other crimes worldwide ranging from sexual aggression to vandalism, from homicide to pyromania can have revenge motivations underlying; while many inmates harbor DoV and none of the five most internationally widespread instruments of risk assessment used for releasing decisions take it as a necessary point of consideration regarding recidivism; and even though at least three personality disorders (avoidance, paranoid and schizoid), PTSD, complicated grief and other stress response syndromes are frequently associated with DoV, which can, on the one hand, imply a high risk for society in criminal perpetration and on the other hand imply a significantly reduction in quality of life for patients, there is no major psychological or empirical research that had studied the DoV enough. Security, health and stability are compromised in our society, so that a deep study aiming to find key factors that serve as incentive for $\mathrm{DoV}$ in both criminal and clinical population, may help in the settlement of prevention and treatment programs addressed to reduce symptomatology and criminal rates that will benefit the society. We are glimpsing the risks, we should find the means.

\section{Social reasons}

Society means interrelations between different groups with different interests, that is why people are often confronted and conflicts arise. Conflicts are part of human nature, conditioning our relations and our psychological state as well. Within this psychological state, DoV could be an interesting factor to take into account.

Bullying happens when a person or a group of people address nasty and unpleasant comments to another one (Olweus, 1993; Whitney \& Smith, 1993), when they beat him, kick him or threaten him (locked him in a room, sent offensives notes to him, nobody talks to him) and the victim finds difficult to defend himself. There is lack of statistics, either because not all cases are detected or because some victims feel ashamed and hide the problem. A 386cases study conducted in 2006 by the Department of Education of the Generalitat of Catalunya, stands prevalence of alleged bullying at $10 \%$; physical violence $6 \%$ and verbal violence $10 \%$. A later study (Nabuzoka, Rønning \& Handegård, 2009) found that out of a total of 575 students, those reporting neither having been victims nor witnessed bullying constituted $56.5 \%$ whereas the rest of the sample, almost a half of the total, had been exposed to bull- 
ying by peers either as witnesses (16.2\%) or directly experiencing bullying behaviour as victims (27.3\%).

Witnesses are relevant at this point because limits with victims are diffusing (Boney-McCoy \& Finkelhor, 1995), and they often suffer similar symptoms as those of directed victims (Garbarino, 2001; Janson \& Hazler, 2004), although there are some differences based on gender. While girls tend to use social support as the preferred strategy to deter the harassment and feeling better (Hunter, Boyle \& Warden, 2004), boys often use physical aggression or harbor DoV towards the perpetrator. Thus, remembering Nabuzoka et. al., (2009), we will be saying that $27.3 \%$ of those reporting having been bullied plus that $16.2 \%$ defined as witnesses and often suffering similar symptoms to directed bullied, were likely to harbor DoV and thus, were likely to become future aggressors.

$\mathrm{DoV}$ in this context may be motivated to do something to stop bullying by the need to exert control and be assertive and by their emotional reactions to bullying (Craig, Pepler \& Blais, 2007). The warning that has to be made is that those who tend to react vindictively, have high probability to become aggressors (Kristensen \& Smith, 2003), this way affecting not only parts entailed but also the social climate in class (Solomon, Watson, Battistich, Schaps \& Delucchi, 1996) given that the cycle of violence is perpetuated.

In fact, some tragic crimes at education centers in which relation bullying-vengeance is present, are well known. Seung-Hui Cho, before killing 32 people in the massacre at Virginia Tech, was bullied by fellow high school students who mocked his shyness and the strange way he talked. He left a manifestolike statement where he expresses rage, resentment and desire to get even (NBC, 2007). Years later, Wellington Menezes de Oliveira shot and killed 12 students at Tasso de Oliveira Municipal School and then committed suicide (Daily Mail, 2011). Analysis of the videotapes found yielded that he felt intensely bullied as a child, and was determined to strike back: "I hope this serves as a lesson, especially to those school officials who stood by with their arms crossed as students were being attacked, humiliated, ridiculed and who were being disrespected," (ABC News, 2011) blaming bullies for his murders: "I want to leave very clear that I am not responsible for the deaths that will occur, even though my fingers will be on the trigger". (BBC News, 2011).

Similar scene can be found in adult world within organizational groups (Morrill, 1995). Mobbing in working life involves hostile and unethical communication which is directed in a systematic manner by one or more individuals, mainly toward one individual, who, due to mobbing, is pushed into a helpless and defenseless position and held there by means of continuing mobbing activities. These actions occur on a very frequent basis (at least once a week) and over a long period of time (at least six months duration). Because of the high frequency and long duration of hostile behavior, this maltreatment results in considerable mental, psychosomatic and social misery (Leymann, 1996). Our legislation has no specific law about it but the INSHT'S Prevention Technical Note $n^{\circ} 476$ develops the concept of mobbing summing up some defining aspects and warning that the victim usually has feelings of rage, resentment and DoV against the perpetrator (INSHT, 1998; Piñuel, 2001; Rodríguez-López, 2004).

An increasing number of studies have explored how subjects respond to perceived unfairness or personal offenses within the organization (for example Aquino, Tripp \& Bies, 2001; 2006; Skarlicki, van Jaarsveld y Walker, 2008), given that revenge may mediate some of the conflicts generated (Wall \& Callister, 1995), or even extreme behaviors in the workplace, such as employee theft (Greenberg, 1990), antisocial behavior (Robinson \& O'LearyKelly, 1998), workplace aggression (Folger \& Skarlicki, 1998), and violence (Folger \& Baron, 1996). Although revenge is not always bad (Bies \& Tripp, 1998), it often leads to violent responses, resulting in perpetuating the cycle of violence (Pruitt \& Rubin, 1986). As it happens with bullying, mobbed victim could turn into aggressor. Another current example is computer sabotage, result of a vindictive attitude, sometimes aiming damaging for the company, sometimes for his/her own advantage. For example, a recent fired employee may have said: "I have deleted their hard disk because the fired me", or another one may have copied client data from the company list and started a new company by himself. Software plagiarism is difficult to 
evidence and it may cost 3.000 euros (Cincodias, 2009), so that many companies raise their expenditures, loose relevant information and their brand image may be affected.

Just in case two prior social contexts where DoV are often released was considered as infrequent and not related to all readers' daily life, although there may be more contexts, last one tackled is revenge while driving. Most of us may have faced common driving situations such as another driver ignoring rules of the road, tail-gating, horn-blowing, and aggressive verbal responses (Deffenbacher, Getting \& Lynch, 1994; Maiuro, 1998). Competitive driving conditions could cause some drivers to operate their vehicles with a disregard for the safety of others. As many commuters drive more aggressively, this may cause others to retaliate, often jeopardizing their own safety. Indeed, a threat to one's well-being can, in the minds of many drivers, justify an even more aggressive response (Wiesenthal, Henessy \& Gibson, 2000). Precisely these last authors considered the relevance that DoV and stress had while driving and elaborated a Driving Vengeance Questionnaire to measure deviant driver's attitudes, a pioneer and very first step through the exploration of vengeance.

Thus, since daily and tragic punctual episodes of violence at schools have been related with high levels of DoV, and given that mobbing and conflicts at working places can derive in feelings of getting even, in both cases swapping victims for aggressors, increasing the probability of new violence with disadvantageous consequences for the community, it may result of interest exploring the DoV to prevent further unpleasant situations and improve social climates. Reducing competitive situations and controlling stress while driving, may improve safety on the road and may decrease number of accidents. But despite all of this, there is no major psychological or empirical research that had studied the DoV enough.

\section{Discussion}

I am aware that I have been talking about DoV without firstly providing a definition of it. In my opinion, this is one of the biggest deficiencies in this field: since being considered as a negative social motive in Miller Motivation Scale (Miller, 1985) and later Frijda's cognitive and emotional approach (1994), there is no deeply and operative definition of what we consider vengeance and DoV are, as well as there is no clear literature on the differences that may exist among DoV, as cognition; and getting even, as action. So with our main parameter looking as a ghostly and ethereal concept, little research can be done, given that every researcher may consider his/her own definition and we will not be talking about the same. My first conclusion is that we need to follow suit Frijda's attempt and research recommendations (1994) so that we get a common definition of vengeance and $\mathrm{DoV}$, as well as pointing the differences that may exist between other concepts related such as retaliation, getting even or revenge. And to demand this need, I have based my argument in four reasons.

First are cultural reasons. All along human history, from ancient to current times, worldwide cultures have engraved the urge to talk about the feeling of getting even and the satisfaction to retaliate, using different words to refer to it. Decades talking about a concrete matter deserve the matter to be studied, and given that language has been used to understand universal and specific psychological aspects, in the case of revenge it would be desirable to pay attention to the linguistics, so we can approach to a common shared definition. The study of mythology, literature, art and other ways of human expression in which revenge has largely appeared will be a great help in this duty as well, allowing us to know how our ancestors considered what vengeance was and how the concept may have evolved.

Second are judicial reasons. It has been shown that the need to response when we are damaged is apparently part of our human nature and this has inspired most penal legislation, although varying along time. At first considered as an individual right, vengeance later began to be bestowed to a third and objective party in order to avoid disproportionate responses and anthropological differences that we have evidenced from social differences among Samurai to noses cut in some Arabian countries. Therefore, firstly codes estimating and balancing damage and punishments appeared, such as 
Hammurabi Code. The retributive system gave way to a restorative system, appearing money as a mean of compensation. Thus, aware of dangerous and violent consequences of vengeance, laws have moved this feeling away trying this way to deter cycles of response-counter response and protecting rights. Not only thinking about victims and offenders but also thinking about juries in order to do the best objective process, there has been some research exploring how to create groups without social prejudices or emotional and vindictive bias that could influence decisions upon defendants. A feeling that inspired laws and relevant changes to the concept of Justice since ancient times, as well as a feeling identified as an obstacle to fair processes would deserve further investigation. Comparative law and anthropological studies could provide abundant information about the influence that vengeance and its desire have in a culture regarding its values, thus making comprehensible that the same crime could have such different punishments in two countries. Further research in creating assessment instruments that allow configure juries as objectives as possible would benefit Justice and confidence of people in it. Moreover, another way of moving DoV away from forensic contexts, such as victim-offender mediation has been thought about, may result a fruitful field of research, so that the victim could feel as a real part of the judiciary system, allowing him/her to find answers to his/her doubts and make the incident understandable drawing preventive advises for the future and may be forgiving the offender removing those ruminative DoV. On the other hand, offender would have the chance to regret and understand the damage caused so that he/she may assume the punishment reducing his/her DoV about being imprisoned unfairly.

Third are criminal and psychological reasons. There is evidence of some psychological disorders prone to act vindictively as well as evidence of some crimes, many of them pretty common in Spain, that usually have DoV underlying. Then, DoV becomes a risk factor for criminality and recidivism, given that even inmates have also shown DoV although none risk assessment instrument include any measure of it. Further research firstly defining the construct and then elaborating reliable and valid instruments and scales measuring DoV, better if including irrational beliefs and beliefs regarding Justice scales, would be recommended to be done, so that psychiatrics, hospitals and prisons could have one more objective resource in their risk assessments. If a factor frequently related to violence is detected on time and prevention programs could be implemented, criminal rate may be reduced, benefiting society. A psychological model explaining the origin and maintenance of DoV may help clinicians in finding therapeutic skills addressed to improve perceived quality of life of patients, benefiting the individual.

Fourth are social reasons. It has been shown that both bullying and mobbing, as two types of harassment, usually imply that victims and even witnesses of violence harbor DoV towards the perpetrators, sometimes turning the tables and becoming aggressors (shooting, theft, computer sabotage...), perpetuating the cycle of violence. Experiences with mediation in educative centers can reduce school violence (Díaz-Aguado, 2006; Johnson \& Johnson, 1999), increase problem solution skills and improve social climate in class (Boqué, 2002; Malik y Herraz, 2005). Relative success is guaranteed with these interventions (Johnson \& Johnson, 2004; Smith, Daunic, Miller \& Robinson, 2002), although there is also evidence at the contrary. Apart from other social contexts, DoV is usual while driving. Some subjects tend to operate their vehicles with a disregard for the safety of others. As many commuters drive more aggressively, this may cause others to retaliate, often jeopardizing their own safety. There is a little research in this, although a threat to one's well-being can, in the minds of many drivers, justify an even more aggressive response (Wiesenthal, Henessy \& Gibson, 2000). In this sense, programs combining stress control and coping DoV may prevent some accidents on the road.

Once every reason summarized, we can conclude that the study of DoV has been weakly explored (Frijda, 1994; Vidmar, 2000) despite the benefits that it has in many ambits both for society and individuals. Most research have been addressed exploring forgiveness, as talking about DoV could be negative or unfruitful. However, in other fields of research, interesting and profitable studies have been recently made, such as social neurosciences (de Quervain, 
Fischbacher, Treyer, Schelhammer, Schnyder, Buck \& Fehr, 2004; Singer, 2012), or comparative psychology and primatology (de Waal, 1991; Jensen, Call \& Tomasello, 2007; McCullough, 2008; Silk, 2007). Two very fertile fields trying to find both neurobiology and adaptative roots of DoV that are stilled juvenile and should be deeply explored to answer questions remaining as well as to improve our integrated knowledge about DoV.

Finally, let me remember that I started the idea of this article reading comics of Batman. Disciplines that at first sight may appear unrelated to our object of study, could finally find a place to work together. Any source of ideas or new knowledge should not be taken as inconsiderable if are able to enhance science. Only a multidisciplinary perspective may accomplish the difficult task to understand as deeply as possible every matter of study. As it was attributed to Hinde, none of us could be competent in so many branches of knowledgment as Da Vinci and Darwin were. However, despite the permanent need for specialization, we should not forget to promote links between branches of science. We need to be prepared to interdisciplinarity. That is, philology, literature, anthropology, law, criminology, psychology, neuroscience and ethology are called to work together in the difficult task to define and explore DoV and vengeance itself. Only with this common effort, we will be nearer to know when Batman will hang his costume.

\section{Acknowledgments}

The effort of this article is inspired in the effort of $\mathrm{H}$.

\section{References}

ABC News (2011). Brazil debates bullying in examining massacre. Retrieved March 7, 2012 from http://abcnews.go.com

Al-Krenawi A. \& Graham J. R., (1999) Social work intervention with Bedouin-Arab children in the context of blood vengeance. Child Welfare, 78, 283-296.

Amnesty International (2011). Condenas y ејесu- ciones en 2010. Madrid: Editorial Amnistía Internacional (EDAI).

Aquino, K, Tripp, T. \& Bies, R. (2001). How employees respond to personal offense: The effec-ts of blame attribution, victim status, and offender status on revenge and reconciliation in the workplace. Journal of Applied Psychology, 86, 52-59.

Aquino K., Tripp, T., \& Bies, R. (2006). Getting even or moving on? Power, procedural justice, and types of offense as predictors of revenge, forgiveness, reconciliation, and avoidance in organizations. Journal of Applied Psychology, 91, 653-668.

Bayer, C. P., Klasen, F., \& Adam, H. (2007). Association of trauma and PSTD symptoms with openness to reconciliation and feelings of revenge among former Ugandan and Congolese child soldiers. Jama-journal of the american medical association, 298, 555559.

BBC News (2011). Brazil: Rio school gunman "motivated by bullying". Retrieved March 7, 2012 from http://www.bbc.co.uk

Bies, R. J. \& Tripp, T. M. (1998). The many faces of revenge: The good, the bad, and the ugly. In R. W. Griffin, A. O'Leary-Kelly, \& J. Collins (Eds.), Monographs in organizational behavior and industrial relations, 23. Dysfunctional behavior in organizations: Part B. Non-violent dysfunctional behavior (pp. 49-67). Greenwich, CT: JAI Press.

Boney-McCoy, S. \& Finkelhor, D. (1995). Psychosocial sequelae of violent victimization in a national youth sample. Journal of Consulting and Clinical Psychology, 63, 726-736.

Boqué, M. C. (2002) Guía de mediación escolar. Barcelona: Octaedro.

Brownlee, S., McGraw, D., \& Vest, J. (1997). The place for vengeance: many grieving families seek comfort and closure in the execution of a murderer. US News and World Report, 122, 24-32.

Cardozo, B. L., Kaiser, R., Gotway, C.A., \& Agani, F. (2003). Mental health, social functioning, and feelings of hatred and revenge of Kosovar Albanians one year after the war in Kosovo. Journal of traumatic stress, 16, 351-360.

Carroll, A. (2009). Are you looking at me? Understanding and managing paranoid personality disorder. Advances in Psychiatric Treatment, $15,40-48$. 
Chikanobu, Y. (1891) The history of the Soga brothers. Retrieved March 9, 2012 from http://ccd1.libraries.claremont.edu/cdm/singleitem/collection/cyw/id/145

Cincodias (2009). El sabotaje informático como venganza de los despedidos. Retrieved 28 February, 2012 from http://www.cincodias.com

Costa, P. T., Jr. \& McCrae, R. R. (1992). Revised NEO Personality Inventory (NEO-PI-R) and NEO Five-Factor Inventory (NEO-FFI) manual. Odessa, FL: Psychological Assessment Resources, Inc.

Counts D. A. (1987). Female suicide and wife abuse: a cross-cultural perspective. Suicide Life Threatening Behavior, 17(3), 194-204.

Craig, W., Pepler, D., \& Blais, J. (2007). Responding to bullying: What works? School Psychology International, 28, 465-477.

Daily mail (2011). Fleeing for their lives: Survivors of Rio school massacre seen on CCTV sprinting away from class where killer opened fire. Retrieved March 7, 2012 from http://www.dailymail.co.uk

Deffenbacher, J. L., Getting, E. R., \& Lynch, R. S. (1994). Development of a driving anger scale. Psychological Reports, 74, 83-91

De Quervain, D. J., Fischbacher, U., Treyer, V., Schelhammer, M., Schnyder, U., Buck, A., \& Fehr, E. (2004). The neural basis of altruistic punishment. Science, 305, 1254-1258.

De Waal F. B. M. (1991). The chimpanzee's sense of social regularity and its relation to the human sense of justice. American Behavioral Scientist, 34, 335-349.

Díaz-Aguado, M. J. (2006). Del acoso escolar a la cooperación en las aulas. Madrid: Prentice Hall.

Douglas, K. S., Webster, C. D., Hart, S. D., Eaves, D., \& Ogloff, J. R. P. (Eds.), (2001). HCR-20: Violence risk management companion guide. Vancouver, British Columbia, Canada/Tampa, FL: Mental Health, Law, and Policy Institute, Simon Fraser University/Department of Mental Health Law \& Policy, University of South Florida.

Dunsieth, N. W., Nelson, E. B., Brusman-Lovins, L. A., Holcomb, J. L., Beckman, D. A., Welge, J. A., ... Mcelroy, S.L. (2004) Psychiatric and legal fea- ture of 113 men convicted of sexual offences. Journal of Clinical Psychiatry, 65, 293-300.

Dutton, D. G. (2007) The abusive personality. Violence and control in intimate relationships $\left(2^{\text {nd }}\right.$ ed.). New York: Guilford Press.

Esbec, E. \& Echeburúa E. (2010) Violencia y trastornos de la personalidad: implicaciones clínicas y forenses. Actas Especiales Psiquiatría, 38(5), 249-261

Folger, R. \& Baron, R. A. (1996). Violence and hostility at work: A model of reactions to perceived injustice. In G. R. Vandenbos \& E. Q. Bulato (Eds.), Workplace violence (pp. 51-85). Washington, DC: American Psychological Asso-ciation.

Folger, R. \& Skarlicki, D. P. (1998). A popcorn metaphor for employee aggression. In R. W. Griffin, A. O'Leary-Kelly, \& J. Collins (Eds.), Monographs in organizational behavior and industrial relations: Vol. 23. Dysfunctional behavior in organizations: Part A. Violent and deviant behavior (pp. 43-81). Greenwich, CT: JAI Press.

Frijda, N. (1987). Emotion, cognitive structure, and action tendency. Cognition and emotion, 1, 115-143. Doi:10.1080/02699938708408043

Frijda, N. (1994). The Lex Talionis: On vengeance. In S. van Goozen; N. Van de Poll \& J.L. Sergeant (Eds.) Essays on emotion theory. New Jersey: Erlbaum Associates.

Gäbler, I. \& Maercker, A. (2011). Revenge phenomena and posttraumatic stress disorder in former East german political prisoners. Journal of Nervous Mental Disease, 199(5), 287-294.

Garbarino, J. (2001). An ecological perspective on the effects of violence on children. Journal of Community Psychology (Special Issue: The Impact of Violence on Children at Home, Community, and National Levels, 29, 361-378.

Generalitat de Catalunya (2006). La mediación escolar como instrumento de participación y pacificación en los centros educativos de Catalunya. Barcelona: Departamento de Educación. Generalitat de Catalunya.

González Guerrero, L. (2007). Características descriptivas de los delitos cometidos por sujetos con trastornos de la personalidad: motivaciones subyacentes, "modus operandi" y relaciones víctima-victimario. Psicopatología clínica, legal y forense, 7, 19-40. 
Greenberg, J. (1990). Employee theft as a reaction to underpayment inequity: The hidden cost of pay cuts. Journal of Applied Psychology, 75, 561-568.

Grimal, P. (1979). Diccionario de mitología griega y romana. Barcelona: Editorial Paidós.

Grimal, P. (1989). La mitología griega. Barcelona: Editorial Paidós Studio 75.

Hamama-Raz Y., Solomon Z., Cohen A., \& Laufer A.. (2008). PTSD symptoms, forgiveness, and revenge among Israeli Palestinian and Jewish adolescents. Journal of Trauma Stress, 21, 521-529. Doi:10.1002/jts.20376

Hanson, R. K., Harris, A. J. R., Scott, T., \& Helmus, L. (2007). Assessing the risk of sexual offenders on community supervision: The Dynamic Supervision Project (Corrections Research User Report No. 2007-05). Ottawa, ON: Public Safety Canada.

Hennessy, D. \& Schwartz, S. (2007). Personal predictors of spectator aggression at little league baseball games. Violence Victimology, 22, 205-215.

Hennessy, D. \& Wiesenthal, D. L. (2004) Age and vengeance as predictors of mild driver aggression, Violence Victimology, 19, 469-477.

Ho, R., FosterLee, L., FosterLee, R., \& Crofts, N. (2002). Justice versus vengeance: motives underlying punitive judgments. Personality and Individual Differences 33, 365-377.

Holbrook M. I. (1997). Anger management training in prison inmates. Psychological Reports, 81, 623-626.

Horowitz M. J. (2001). Stress Response Syndromes: Personality Styles and Interventions $\left(4^{\text {th }}\right.$ ed.). Northvale, NJ: Aronson.

Horowitz, M. J. (2007). Understanding and ameliorating revenge fantasies in psychotherapy. American Journal of Psychiatry, 164, 24-27.

Hunter, S. C., Boyle, J. M. E., \& Warden, D. (2004). Help seeking amongst child and adolescent victims of peer-aggression and bullying: The influence of school-stage, gender, victimization, appraisal, and emotion. British Journal of Educational Psychology, 74, 375-390.

INE (2012). Estadística de condenados/Estadística de menores (code IOE 30466). Madrid: INE. Retrieved from www.ine.es March 9, 2012.

INSHT (1998). Nota Técnica Preventiva número
476. Retrieved February 27, 2012 fromhttp://www.insht.es

Janson, G. R. \& Hazler, R. J. (2004). Trauma reactions of bystanders and victims to repetitive abuse experiences. Violence and Victims, 19, 239-255.

Jensen, K., Call, J., \& Tomasello, M. (2007). Chimpanzees are vengeful but not spiteful. $\mathrm{Na}$ tional Academy of Sciences, 104, 13046-13050. Doi:10.1073/pnas.0705555104

Johnson, D. W. \& Johnson, R. T. (1999) Cómo reducir la violencia en las escuelas. Buenos Aires: Paidós.

Johnson, D. W. \& Johnson, R. T. (2004). Implementing the "Teaching students to be peacemakers program". Theory into practice, 43(1), 68-79.

Kane, B. (1940). The legend of the Batman. Detective Comics. Spring Issue. $\mathrm{N}^{\mathrm{o}} 1$.

Kristensen, S. \& Smith, P. K. (2003). The use of coping strategies by Danish children classed as bullies, victims, bully/victims, and not involved, in response to different (hypothetical) types of bullying. Scandinavian Journal of Psychology, 44, 479-488.

Kropp, P. R., Hart, S. D., Webster, C. D., \& Eaves, D. (1995). Manual for the Spousal Assault Risk Assessment Guide (2nd edition). Bristish Columbia: The British Columbia Institute on Family Violence.

Kunst, M. J. (2011). PTSD symptom clusters, feelings of revenge, and perceptions of perpetrator punishment severity in victims of interpersonal violence. International Journal of Law and Psychiatry. 34, 362-367.

Leue, A., Borchard, B., \& Hoyer, J. (2004) Mental disorders in a forensic sample of sexual offenders. European Psychiatry, 19(3), 123-130.

Lewis, M., Haviland-Jones, J. M., \& Feldman, L. (2008). Handbook of emotions. New York: The Guilford Press.

Leymann, H. (1996). The Content and Development of Mobbing at Work. European Journal of Work and Organizational Psychology, 5(2), 165-184.

Maiuro, R. D. (1998). Rage on the road. Recovery, 9(2), 8-9.

Malik, B. \& Herraz, M. (2005). Mediación intercultural: bases conceptuales e introducción. In B. Malik y M. Herraz (coords.), Mediación intercultural en contextos socio-educativos. Málaga: Aljibe. 
Marshall W. L. (2007). Diagnostic issues, multiple paraphilias, and comorbid disorders in sexual offenders: Their incidence and treatment. Aggression and Violent Behavior, 12, 16-35. Doi: 10.1016/j.awb.2006.03.001

Mazzola, R. F. (2007). Reconstruction of the nose-a historical review. Handchir Mikrochir Plast Chir, 39, 181-188.

Mcclelland, R. T. (2010). The pleasures of revenge. Journal Of Mind And Behavior, 31(3-4), 195-235.

McCullough, M. E. (2008). Beyond revenge. The evolution of the forgiveness instinct. San Francisco, California: Jossey Bass.

Mckee, I. R. \& Feather, N. T. (2008). Revenge, retribution, and values: Social attitudes and punitive sentencing, Social Justice Research, 21, 138-163.

Menander, M. (2005). The ethics of Confucius. New York: Cossimo Classics Sacred Texts.

Milgram, N., Stern, M., \& Levin, S. (2006). Revenge versus forgiveness/forbearance in response to narrative-simulated victimization. Journal of Psychology, 140, 105-119.

Miller, H. J. (1985). The Miller Motivation Scale: a new counseling and research tool. Regina: Meta Development.

Mills, D. E. (1976). Kataki-uchi: The Practice of Blood-Revenge in Pre-Modern Japan. Modern Asian Studies, 10, 525-542.

Moore, A. \& Lloyd, D. (1988). The absolute $V$ for vendetta. Dc Comics. Spanish edition: V de Vendetta. Barcelona: Editorial Planeta de Agostini. Vértigo, 2010.

Morrill, C. (1995). The executive way. Chicago: University of Chicago Press.

Nabuzoka, D., Rønning, J. A., \& Handegård B. H. (2009). Exposure to bullying, reactions and psychological adjustment of secondary school students Educational Psychology, 29, 849-866.

NBC (2007). High school classmates say gunman was bullied. Retrieved March 7, 2012 from http://www.msnbc.msn.com

Ney, P. (1987). The treatment of abused children: the natural sequence of events. American Journal of Psychotherapy, 41, 391-401.

Noreik, K., \& Grünfeld B. (1990). Forensic psychiatric examination of arsonists, Tidsskr Nor Laegeforen, 110, 1820-1822.
Novaco, R. W. (1991). Aggression on roadways. In $\mathrm{R}$. Baenninger (Ed.), Targets of violence and aggression. (pp. 253-326). North-Holland: Elsevier Science Publisher.

Novaco, R. W. (2010). Anger and psychopathology. In M. Potegal, G. Stemmler, C.Spielberger (Eds.), International handbook of anger. Constituent and concomitant biological, psychological, and social processes (pp. 465-497). New York: Springer.

Nygaard, R. L. (1994). "Vengeance is mine" says the Lord. America, 171, 6-9.

Olweus, D. (1993). Bullying in school: What we know and what we can do. Oxford: Blackwell.

Orth, U., Montada, L., \& Maercker, A. (2006). Feelings of revenge, retaliation motive and posttraumatic stress reactions in crime victims. Journal of interpersonal violence, 21, 229-243.

Pardini, D. (2011). Perceptions of social conflicts among incarcerated adolescents with callous unemotional traits: 'You're going to pay. It's going to hurt, but I don't care. Journal of child psychology and psychiatry, 52, 248-255. Doi:10.1111/j.14697610.2010.02336.X

Piñuel, I. (2001). Mobbing. Cómo sobrevivir al acoso psicológico en el trabajo. Santander: SalTérrae.

Porporino, F., Doherty, P., \& Sawatsky, T. (1987). Characteristics of homicide victimizations in Canadian federal correctional institutions during two historical periods: 1967-1978 and 19791984. International Journal of Offender Therapy and Comparative Criminology, 31, 125-136.

Pruitt, D. G. \& Rubin, J. Z. (1986). Social conflict: Escalation, stalemate, and settlement. New York: Random House.

Quinsey, V. L., Harris, G. T., Rice, M. E., \& Cormier, C. A. (2006). Violent offenders: Appraising and managing risk. The law and public policy (2nd Ed.). Washington DC: American Psychological Association.

Quinsey, V. L., Rice, M. E., \& Harris, G. T. (1995). Actuarial Prediction of Sexual Recidivism. Journal of Interpersonal Violence, 10, 85-105.

Robinson, S. L. \& O'Leary-Kelly, A. (1998). Monkey see, monkey do: The influence of work groups on the antisocial behavior of employees. Academy of Management Journal, 41, 658-672.

Rodríguez-López, P. (2004). El acoso moral en el 
trabajo. La responsabilidad en el acoso moral en el trabajo. Madrid: Dijusa.

Sánchez-Bernardos, M. L. (1997). Los trastornos de la personalidad y el modelo de los Cinco factores. Relaciones empíricas. Clínica y Salud, 6, 175188.

Scully, D. \& Marolla, J. (1985). "Riding the bull at Gilley's": Convicted rapists describe the rewards of rape. Social Problems, 32, 251-263.

Silk, J. B. (2007). Chimps don't just get mad, they get even. National Academy of Sciences, 104, $13537-$ 13538. Doi:10.1016/j.neuroimage.2012.01.109

Singer, T. (2012). The past, present and future of social neuroscience: A European perspective. Neuroimage (in press).

Skarlicki, D. P., van Jaarsveld, D. D., \& Walker D. D. (2008). Getting even for customer mistreatment: the role of moral identity in the relationship between customer interpersonal injustice and employee sabotage. Journal of Applied Psychology, 93, 1335-1347.

Smith, S. W., Daunic, A. P., Miller, M. D., \& Robinson, T. R. (2002). Conflict resolution and peer mediation in middle schools: Extending the conflict resolution process and outcome knowledge base. Journal of Social Psychology, 142, 567586. Doi:10.1080/00224540209603919

Solomon, D., Watson, M., Battistich, V., Schaps, E., \& Delucchi, K. (1996). Creating classrooms that students experience as communities. American Journal of Community Psychology, 24, 719-748.

Solomon, R. C., (1994). Sympathy and vengeance: the role of the emotions in justice. In S. van Goozen, N. Van de Poll \& J. L. Sergeant (Eds.) Essays on emotion theory. New Jersey: Erlbaum Associates.

Sonis, J., Gibson, J. L, de Jong, J. T. V. M., Field, N. P., Hean, S., \& Komproe, I. (2009). Probable Posttraumatic Stress Disorder and Disability in Cambodia Associations With Perceived Justice, Desire for revenge, and Attitudes Toward the Khmer Rouge Trials. Jama-Journal of the American medical association, 302, 527-536.
Sprober, N. \& Fegert, J. M (2010). Rampage: And now I take revenge! - Is there a correlation between (cyber-)bullying and rampages in schools? Nervenheilkunde, 29, 442-445.

Stone, M. H. (2001). Serial sexual homicide: Biological, psychological, and sociological aspects. Journal of Personality Disorders, 15, 1-18.

Stuckless, N. \& Goranson, R. (1992). The Vengeance Scale: Development of a Measure of Attitudes Toward Revenge , Journal of Social Behavior and Personality, 7, 25.

Stuckless, N., Ford, B. D., \& Vitelli, R. (1995), Vengeance, anger and irrational beliefs in inmates: A caveat regarding social desirability. Personality and Individual Differences, 18, 1-6. Doi: 10.2466/pr0.1988.62.3.855

Terris, W. \& Jones, J. (1982). Psychological factors related to employees's theft in the convenience store industry. Psychological Reports, 51, 12191238.

Turner, C. \& Cashdan, S. (1988). Perceptions of college students' motives for shoptlifting. Psychological Reports, 62, 855-862.

Vidmar, N. (2000). Retribution and revenge. In J. Sanders\&V. L. Hamilton (Eds.), Handbook of justice research in law (pp. 31-63). New York: Kluwer

Wall, J. A. (Jr.) \& Callister, R. R. (1995). Conflict and its management. Journal of Management, 21, 515-558. Doi:10.1080/001318893030350101

Whitney, I. \& Smith, P. K. (1993). A survey of the nature and extent of bullying in junior/ middle and secondary schools. Educational Research, $35,3-25$.

Wiesenthal, D. (1990). Psychological aspects of vandalism. In R. Takens (Ed.), European perspectives in social psychology (vol. 3) (pp. 279-297). Essex: Wiley.

Wiesenthal, D. L., Hennessy, D., \& Gibson, P. (2000). The driving vengeance questionnaire (DVQ): the development of a scale to measure deviant driver's attitudes. Violence and Victims, 15(2), 115-136.

Manuscrito recibido: 09/03/2012

Revisión recibida: 21/04/2012

Aceptado: 11/05/2012 